\title{
Factors That Affect Self-directed Learning of Faculty Nursing Students at Minia University
}

\author{
Faten Ali Ahmed ${ }^{1}$, Refaat Raouf Sadek ${ }^{1}$, Hala Ramzy Yousef ${ }^{1} \&$ Sanaa Mohammed Aref ${ }^{1}$. \\ 1. Faculty of Nursing - Minia University. \\ 2. Faculty of Medicine - Minia University \\ 3. Faculty of Nursing - Assiut University
}

\begin{abstract}
This study aimed to detect the factors that affect nursing students' self-directed learning at faculty of nursing in Minia University. Setting: The present study was conducted at nursing faculty in Minia University. Research design: This study used descriptive comparative research design. Subjects: Subjects of the study included a total coverage sample of all four academic years nursing students during academic year (2013-2014). Total number of students were $(n=777)$. Tools of data collection included two parts, part one: demographic characteristics of the sample, Part two comprised of scale for self-directed learning factors (three major factors subtitled by 60 statements) Results: female nursing students have the highest mean score for all major factors related to feeling successful and satisfied in studies and their characteristics which were 28.45, 44.19 and 145 respectively. The 1st year nursing students have the highest mean score for the same factors were $(29.75 \pm 4.37),(44.91 \pm 5.42)$ and $(1.51 \mathrm{E} 2 \pm 19.04)$ respectively. Conclusions: the $1^{\text {st }}$ year nursing students and female students have the highest mean score for all major factors. This study recommended providing self-directed learning opportunities for promoting SDLR of the nursing students by motivating them and providing training, and educational resources for carrying out teaching learning process.
\end{abstract}

\section{Keywords: Self-Directed Learning (SDL) \& Self-Directed Learning Readiness (SDLR).}

\section{Introduction}

In learning environment, faculty staff provide students with models of the nursing role, they are the reference group. The models of standers as well as behaviors for professional nursing Saber, (1995)

The teacher helps students to make a smooth transition from teacher-directed to self-directed learning. So he/she must assess the readiness of his students' for the method, establish the boundaries of the students' decisions about their learning and teach about the methodology (Iwasiw, 2014)

Also educator should manage teaching time effectively by planning, organizing, directing, guiding, following up and evaluating all of the available resources (human and physical). (Kan, \& Staber, 2009)

Therefore the teacher in SDL moves to provocation instead of recitation, from instruction to guidance, from telling to asking, and teaching students to think and find out for themselves. (Nantz, \&Klaf, 2012)

The teacher use teaching strategies to support students to be independent. These teaching strategies shift to be learning strategies when the students can independently select the suitable ones and effectively use them to perform activities and tasks and to achieve goals. Effective teaching learning strategies can be applied for different grade levels and subject areas, and can adjust for student differences, motivate and support students to focus their attention, organize information to understand and monitor learning. (HLSGI, 2002, Oxford, 2009) Learning Strategy instruction focuses on making students more active learners by teaching them how to learn and how to use what they have learned to be successful Joseph, \& Hall, (2009)

When students become self-directed learners they are aware of their needs and interests which are important for the process of self-directed learning process. The interest and desire of the learners to learn result in beingsatisfied while the student is conducting the learning activity Webster, (2012), such as participation in study groups, self-guided reading, electronic dialogue, reflective writing activities and internships. Hiemstra, (1994) Ambrose, et al., (2010) stated that student important role is to bea self-directed learner: Students should learn to assess and accommodate their approaches to learning, to become self-directed learners.

Self-directedlearners prefer to be engaged in their learning...not just listening but doing ,Adult learners are self-directed they seek out learning activities to enhance their own knowledge-and especial to meet a need, wants to draw on their rich personal and professional experiences. (TADTS, 2014)

Successful learners use step-by-step strategy, different learningdimension and learning materials, suitablehelpin the form ofmodeling, guiding and 
autonomy in practice, chances to transfer experiences from one situation to another, rational connections between skills and ideas, and real-life situations, chances to show what they know, reinforcement to self-monitor, different tools for evaluating own learning. (Rosenshine, 2012)

\section{Significance of the study}

According to my experience in nursing education and many previous researches addressed self-directed learning, and recommended to do more researches on this topic because nursing field is an ever changing field, so preparing students to be self-directed learners for lifelong learning.To be independent learner the student must be motivated and satisfied with his studies, added to the student characteristics and studying behaviors that affect directly their readiness for self-directed learning, so investigating the previous factors affecting SDL may help in improvement of nursing education.

\section{Aims of the Study}

The aim of this study was to investigate the factors that affect self-directed learning readiness according to the nursing students' opinions at faculty of nursing in Minia University.

\section{Research questions:}

What are the factors that influence the readiness for self-directed learning in different academic years and different gender?

\section{Subject \& Method \\ Study Design}

descriptive comparative research design was applied.

\section{Setting}

The present study was conducted at faculty of nursing in Minia University.

\section{Subjects}

The sample of the study included all four academic years nursing students at Faculty of Nursing in Minia University during academic years 2013-2014.

\section{Data collection tools}

The study tool included two parts:

- A sheet for personal data was used to collect information about nursing students at Minia University including name, age, gender, and academic year.

- A scale for Factors affectingthe readiness of selfdirected learning (Adopted. By Huang, 2008). It included three parts related to three major factors subtitled by 60 sub-items or specific factors. The first major factor related to when the student feels successful (8 statements), the second major factor related to when the student feels satisfied with studies (12 statements), the third major factor related to the characteristics of student studying behaviors (40 statements). The used scoring system is rated on a 5-point likert scale from Grade (1): never or rarely true. Grade (2): sometimes true Grade (3): half the time true. Grade (4): frequently true. Grade (5): always or almost always true.

\section{Pilot study}

A pilot study was performed for 78 students from faculty of nursing students at Minia University. Thus, as no modification in the study sheet needed as the questions were clear and understandable, the pilot study included in the main study sample . Reliability of A scale for Factors affecting the readiness of selfdirected learning is measured by a cronbach's $\alpha=$ $(96 \%)$ statistical method.

\section{Fieldwork}

A paper for official permission was signed from the Dean of nursing faculty in Minia University for the collection of the needed data. After the study tool was finalized, the collection of actual data was started in November 2013 and ended in June 2014. In the presence of the researcher with nursing students the questionnaire distributed and completed to be sure that all items were answered for those who agreed to participate. The whole duration for data collection took about eight months.

\section{Ethical considerations}

A consent from the participants for the agreement was taken orally after explaining their rights to participate, refuse, or withdraw at any time. Total confidentiality of any obtained information was confirmed. The study operation did not include any harmful effects on participants.

\section{Statistical analysis}

The analysis of the data was done by the statistical package for social science (SPSS) version (17), numerical data were expressed as mean and SD, comparison between two variables was done using ttest and four variables by ANOVA test were also used. Significant is considered at $(\mathrm{p}<0.05)$.

\section{Vol , (6) No , (13) April 2018}


Results

Table (1): Distribution of nursing students according to demographic characteristics $(n=777)$.

\begin{tabular}{|c|c|c|}
\hline Characteristics & $\mathbf{N}$ & $\%$ \\
\hline $\begin{array}{c}\text { A- Academic year } \\
-1^{\text {st }} \\
-2^{\text {nd }} \\
-3^{\text {rd }} \\
-4^{\text {th }}\end{array}$ & $\begin{array}{l}212 \\
224 \\
162 \\
179\end{array}$ & $\begin{array}{c}27.3 \% \\
28.8 \% \\
20.9 \% \\
23 \%\end{array}$ \\
\hline $\begin{aligned} \text { B- Gender } & \\
- & \text { Male } \\
- & \text { Female }\end{aligned}$ & $\begin{array}{l}274 \\
503 \\
\end{array}$ & $\begin{array}{l}35 \% \\
65 \% \\
\end{array}$ \\
\hline Total & 777 & $100 \%$ \\
\hline
\end{tabular}

Table (2): Student feeling successful with studies as reported by the studied subject $(n=777)$.

\begin{tabular}{|c|l|c|c|}
\hline \multicolumn{3}{|c|}{ When did you feel most successful } \\
\hline $\mathbf{N}$ & \multicolumn{1}{|c|}{ Items } & Mean & Percentage of mean \\
\hline $\mathbf{1}$ & When a lecture or tutorial made you think about things & 3.683 & $73.7 \%$ \\
\hline $\mathbf{2}$ & When you did almost no work and got away with it & 3.641 & $72.8 \%$ \\
\hline $\mathbf{3}$ & When you got a higher mark than other students & 3.992 & $79.9 \%$ \\
\hline $\mathbf{4}$ & When you learned something interesting & 4.153 & $83 \%$ \\
\hline $\mathbf{5}$ & When you showed people that you were smart & 2.529 & $50.9 \%$ \\
\hline $\mathbf{6}$ & When something you learned make you want to find out more & 4.058 & $81.2 \%$ \\
\hline $\mathbf{7}$ & When you didn't have to work too hard. & 3.534 & $70.9 \%$ \\
\hline $\mathbf{8}$ & $\begin{array}{l}\text { When you were the only one who could answer the lecturer's } \\
\text { questions }\end{array}$ & 2.337 & $46.7 \%$ \\
\hline \multicolumn{3}{|l|}{$* * *$ The negative statements have been reversed in direction } \\
\hline
\end{tabular}

Table (3): Student feeling satisfied with studies as reported by the studied subject $(n=777)$.

\begin{tabular}{|c|l|c|c|}
\hline \multicolumn{3}{|c|}{ How satisfied did you feel when you... } \\
\hline $\mathbf{N}$ & \multicolumn{1}{|c|}{ Items } & Mean & Percentage of mean \\
\hline $\mathbf{1}$ & Learned something new & 3.798 & $76 \%$ \\
\hline $\mathbf{2}$ & Did better than the other students in the class & 2.230 & $44.6 \%$ \\
\hline $\mathbf{3}$ & $\begin{array}{l}\text { Realised you were getting through the course without } \\
\text { having to work hard }\end{array}$ & 2.886 & $57.7 \%$ \\
\hline $\mathbf{4}$ & Read something interesting & 3.898 & $78 \%$ \\
\hline $\mathbf{5}$ & Realised you didn't have to prepare for tutorials. & 2.918 & $58.4 \%$ \\
\hline $\mathbf{6}$ & Worked on a challenging task or assignment. & 3.775 & $75.5 \%$ \\
\hline $\mathbf{7}$ & Accomplished something that others couldn't do. & 3.938 & $78.8 \%$ \\
\hline $\mathbf{8}$ & Understood something from the first time. & 4.030 & $80.6 \%$ \\
\hline $\mathbf{9}$ & Were involved totally in something that you were doing. & 3.942 & $78.8 \%$ \\
\hline $\mathbf{1 0}$ & Received recognition or prestige & 3.982 & $79.6 \%$ \\
\hline $\mathbf{1 1}$ & Enhance your status in the group & 3.806 & $76.1 \%$ \\
\hline $\mathbf{1 2}$ & I like to be the top person in my group & 3.922 & $78.4 \%$ \\
\hline
\end{tabular}


Table (4): Characteristics of student studying behavior as reported by the studied subject $(n=777)$

\begin{tabular}{|c|c|c|c|}
\hline $\mathbf{N}$ & Items & Mean & Percentage of mean \\
\hline 1 & I solve problems using a plan & 3.417 & $68.3 \%$ \\
\hline 2 & I priorities my work & 3.817 & $76.3 \%$ \\
\hline 3 & I do not manage my time well & 2.991 & $59.8 \%$ \\
\hline 4 & I have good management skills & 3.543 & $70.9 \%$ \\
\hline 5 & I set strict time frames & 3.318 & $66.4 \%$ \\
\hline 6 & I prefer to plan my own learning & 3.683 & $73.7 \%$ \\
\hline 7 & I am systematic in my learning & 3.387 & $67.8 \%$ \\
\hline 8 & I am able to focus on a problem & 3.712 & $74.2 \%$ \\
\hline 9 & I need to know why & 3.74 & $74.8 \%$ \\
\hline 10 & I critically evaluate new ideas & 3.555 & $71.1 \%$ \\
\hline 11 & I prefer to set my own learning goals & 3.776 & $75.5 \%$ \\
\hline 12 & I learn from my mistakes & 3.874 & $77.5 \%$ \\
\hline 13 & I am open to new ideas & 3.762 & $75.2 \%$ \\
\hline 14 & $\begin{array}{l}\text { When presented with a problem I cannot resolve, I will ask for } \\
\text { assistance }\end{array}$ & 2.763 & $55.3 \%$ \\
\hline 15 & I am responsible & 3.812 & $76.2 \%$ \\
\hline 16 & I like to evaluate what I do & 3.803 & $76 \%$ \\
\hline 17 & I have high personal expectations & 3.897 & $77.9 \%$ \\
\hline 18 & I have high personal standards & 3.752 & $75 \%$ \\
\hline 19 & I have high beliefs in my abilities & 3.762 & $75.2 \%$ \\
\hline 20 & I am aware of my own limitations & 3.79 & $75.8 \%$ \\
\hline 21 & I am confident in my ability to search out information & 3.629 & $72.6 \%$ \\
\hline 22 & I do not enjoy studying & 2.896 & $57.9 \%$ \\
\hline 23 & I have a need to learn & 3.721 & $74.4 \%$ \\
\hline 24 & I enjoy a challenge & 3.745 & $74.9 \%$ \\
\hline 25 & I want to learn new information & 3.815 & $76.3 \%$ \\
\hline 26 & I enjoy learning new information & 3.73 & $74.6 \%$ \\
\hline 27 & I set specific times for my study & 3.431 & $68.6 \%$ \\
\hline 28 & I am self-disciplined & 3.561 & $71.2 \%$ \\
\hline 29 & I like to gather the facts before I make a decision & 3.561 & $71.2 \%$ \\
\hline 30 & I am disorganized & 3.122 & $62.5 \%$ \\
\hline 31 & I am logical & 3.605 & $72.1 \%$ \\
\hline 32 & I am methodical & 3.395 & $67.9 \%$ \\
\hline 33 & I evaluate my own performance & 3.539 & $70.8 \%$ \\
\hline 34 & I prefer to set my own criteria on which to evaluate my performance & 3.64 & $72.8 \%$ \\
\hline 35 & I am responsible for my own decisions/actions & 3.855 & $77.1 \%$ \\
\hline 36 & I can be trusted to pursue my own learning & 3.69 & $73.8 \%$ \\
\hline 37 & I can find out information for myself & 3.635 & $72.7 \%$ \\
\hline 38 & I like to make decisions for myself & 3.748 & $75 \%$ \\
\hline 39 & I prefer to set my own goals & 3.833 & $76.7 \%$ \\
\hline 40 & I am not in control of my life & 3.215 & $64.3 \%$ \\
\hline
\end{tabular}


Table (5): Comparison among different years of nursing students related to major factors that affect SDLR* as reported by studied subject $(n=777)$.

\begin{tabular}{|c|c|c|c|c|c|}
\hline Major Factors & Academic year & $\mathbf{N}$ & Mean \pm SD & $\mathbf{F}$ & Sig \\
\hline \multirow{4}{*}{ 1- when usually feeling successful. } & $1^{\text {st }}$ & 212 & $29.75 \pm 4.37$ & \multirow{4}{*}{23.345} & \multirow{4}{*}{$.000(* *)$} \\
\hline & $2^{\text {nd }}$ & 224 & $28.06 \pm 4.28$ & & \\
\hline & $3^{\text {rd }}$ & 162 & $26.1 \pm 3.94$ & & \\
\hline & $4^{\text {th }}$ & 179 & $27.26 \pm 4.75$ & & \\
\hline \multirow{4}{*}{$\begin{array}{l}\text { 2- when usually feeling satisfied } \\
\text { with studies. }\end{array}$} & $1^{\text {st }}$ & 212 & $44.91 \pm 5.42$ & \multirow{4}{*}{11.292} & \multirow{4}{*}{$.000(* *)$} \\
\hline & $2^{\text {nd }}$ & 224 & $43.38 \pm 6.59$ & & \\
\hline & $3^{\mathrm{rd}}$ & 162 & $41.31 \pm 6.32$ & & \\
\hline & $4^{\text {th }}$ & 179 & $42.34 \pm 6.77$ & & \\
\hline \multirow{4}{*}{$\begin{array}{l}\text { 3-The characteristics of your study } \\
\text { behavior }\end{array}$} & $1^{\mathrm{st}}$ & 212 & $1.51 \mathrm{E} 2 \pm 19.04$ & \multirow{4}{*}{17.442} & \multirow{4}{*}{$.000(* *)$} \\
\hline & $2^{\text {nd }}$ & 224 & $1.44 \mathrm{E} 2 \pm 22.09$ & & \\
\hline & $3^{\text {rd }}$ & 162 & $1.39 \mathrm{E} 2 \pm 18.11$ & & \\
\hline & $4^{\text {th }}$ & 179 & $1.38 \mathrm{E} 2 \pm 23.48$ & & \\
\hline
\end{tabular}

*N.B (SDLR): self-directed learning readiness.

$(* *)$-Means there is significant differences $(<0.05)$.

Table (6): Differences between males and females nursing students by Using T-Test related to major factors that affect SDLR*.

\begin{tabular}{|l|c|c|c|c|c|c|}
\hline \multicolumn{1}{|c|}{ Major factors } & gender & $\mathbf{N}$ & mean & T & DF & $\begin{array}{c}\text { Sig. } \\
\text { (2-tailed) }\end{array}$ \\
\hline 1-When usually feeling successful. & $\begin{array}{c}\mathrm{M} \\
\mathrm{F}\end{array}$ & $\begin{array}{c}274 \\
503\end{array}$ & $\begin{array}{c}26.96 \\
28.45\end{array}$ & -4.428 & 775 & $.000(* *)$ \\
\hline 2-When usually feeling satisfied with studies. & $\mathrm{M}$ & 274 & 41.17 & -6.445 & 775 & $.000(* *)$ \\
\hline 3- The characteristics of your study behavior & $\begin{array}{c}\mathrm{M} \\
503\end{array}$ & $\begin{array}{c}274 \\
503\end{array}$ & $\begin{array}{l}1.41 \mathrm{E} 2 \\
1.45 \mathrm{E} 2\end{array}$ & -2.806 & 775 & $.005(* *)$ \\
\hline (**) - Means there is significant differences (< 0.05).
\end{tabular}

*N.B (SDLR): self-directed learning readiness.

Table (1): This table described the demographic characteristics of the studied subjects. It revealed that the highest percentage of them were females $(65 \%)$. The highest percentage of students in different academic years was among the second year students it was $28.8 \%$.

Table (2): In relation to when the student feels most successful, the highest percentage of mean for factor no. 4 was $(83 \%)$ which is: when you learned something interesting. And the lowest percentage of mean for factor no. 8 was $(46.7 \%)$ which is: when you were the only one who could answer the lecturer's questions.

Table (3): In relation to student feels satisfied with studies, the highest percentage of mean for factor no. 8 was $(80.6 \%)$ which is: understood something from the first time. And the lowest percentage of mean for factor 2 was $(44.6 \%)$ which is: did better than the other students in the class.

Table (4): In relation to characteristics of students studying behavior, the highest percentage of mean score for factor no. 17, 12, and 35 related to: I have high personal expectations $(77.9 \%)$, and: I learn from my mistakes(77.5\%), and:I am responsible for my own decisions/actions(77.1\%). While the lowest percentage of mean score for factor no. 14 related to: when presented with a problem I cannot resolve, I will ask for assistance, was (55.3\%).

Table (5): In relation to the comparison among different years of nursing students, table(5) revealed that there were statistical significant differences among groups. 
The 1st year students have the highest mean for factors (1), (2) and (3) related to when usually feeling successful, when usually feeling satisfied with studies and the characteristics of your study behavior, were $(29.75 \pm 4.37),(44.91 \pm 5.42)$ and $(1.51 \mathrm{E} 2 \pm 19.04)$ respectively.

Third year students have the lowest mean in factors (1) and (2) related to: when usually feeling successful, and when usually feeling satisfied with studies, were $(26.1 \pm 3.94)$ and $(41.31 \pm 6.32)$ respectively.

In relation to differences between males and females nursing students, it was observed that there were statistical significant differences between males and females nursing students regarding factors 1 and 2 and 3. Females had the highest mean in the previous factors which were related to: when usually feeling successful and when usually feeling satisfied with studies, and the characteristics of your study behavior as shown in table (6).

\section{Discussion}

Self-directed learning requires the ability to identify one's own learning needs, develop and implement a plan to gain knowledge and to monitor one's own progress. (Van Rensburg, \&Botma, 2015). A high percentage of nursing students were female -nearly double the number. This finding might be referred to the acceptance of the society to the idea of being female nurse than being a male nurse and nursing profession commonly was known be female long time ago. This finding was consistent with Walling (2011) who mentioned that the entering of male to the nursingprofession has been increase; it is still a female-dominated occupation. Regarding to $1^{\text {st }}$ year nursing students had the highest mean and percentage of when usually feeling successful and feeling satisfied with studies, and the characteristics of your study behavior.

This might be attributed to student enrolling in nursing college with high expectation and high selfesteem, because nursing nowadays attract scientific students ambitious to achieve high grades.

This finding was compatible to Chaves, et al., (2013) who stated that most of the $1^{\text {st }}$ year nursing students presented high self-esteem, which was related to the professional perspective.

This finding was in contrast to Andrew, et al., (2009)indicated that while most of 1 st year nursing students seem to understand the role for being nursing students, this understanding of what is expected from them is less clear. And, Hakim (2014) added that most $1^{\text {st }}$ year nursing students had little satisfaction concerning their field of study.

Female nursing students have the highest mean of feeling successfully and feeling satisfied and characteristics of study behavior. These finding were consistent with Reio\& Choi (2004) \& Reio \& Davis (2005) who stated that female students had higher level of the self-directed learning than male students. the highest percentages regarding nursing students feeling satisfied was for "understood something from the first time" and "learning something interesting".

This might be due to students accustomed tounderstand from several repeating and not allowed to choose interesting topics, so new and interesting information motivate them to learn more and increase their satisfaction.

This finding is matched with Truby (2010), Clifton \& Mckillup (2012) who mentioned that nursing student showed satisfaction with the course content, learning materials, students will be more motivated when given choices, doing something one chooses rather than what one has been told to do, can be very motivating.

Furthermore, Joshoa (2013), Douglass \& Morris (2014) stated that the most successful students are those who feel real ownership of their education. Students feel personally can make a difference in their own outcomes and that education will make a difference for their future.

Moreover, Williams \& Williams (2011) clarified that students' success creates self-confidence to engage more in learning, students experience success in their understanding, feel some ownership of a decision when agree to it.

The highest percentage of mean score regarding "characteristics of student studying behavior" was for "having highly personal expectation" and "students learn from their mistakes".

This finding might be due to students trust in selfabilities and accustomed to learn from the trial and error when teachers inform students about mistakes and give immediate feedback this might help students try not to repeat the same mistakes every time.

This finding is supported byMarann\& Barbara (2005), Evans \& Stevenson (2009) who reported that students who have strong self-belief and high personal expectations and high levels of selfconfidence are more likely to actively participate in learning tasks than those who doubt their abilities.

Charles \& Kathleen (2009) asserted that even during carefully planned lessons, students make mistakes, answer incorrectly, give incomplete answers, or do not respond at all, students learn by doing, but if errors are repeated, students may be learning how to perform skills incorrectly. Students learn better by "doing with feedback." The biggest problem with delayed feedback is that it allows students to practice errors. 


\section{Conclusions}

- The first year nursing students have the highest mean score in relation to major factors no. 1 "Student feeling successful with studies", no. 2 "Student feeling satisfied with studies", and 3 "Characteristics of student studying behavior".

- the female nursing students have the highest mean score in relation to major factors no. 1 "Student feeling successful with studies", no. 2 "Student feeling satisfied with studies", and 3 "Characteristics of student studying behavior".

\section{Recommendations}

- Providing self-directed learning opportunities for promoting SDLR of the nursing students by motivating them and providing training, and educational resources for carrying out teaching learning process.

- Recommend the nursing faculty staff members to motivate nursing students to use self-directed learning activities.

- Provide information through discussion and seminars to increase the nursing students' awareness about importance and self-directed learning activities.

\section{References}

1. Ambrose, S., Bridges, M., DiPietro, M., Lovett, M., \& Norman, K., (2010): How Learning Works: Seven Research-Based Principles for Smart Teaching. San Francisco: Jossey-Bass. 2010.

2. Andrew N., McGuinness C., Reid G.and Corcoran T., (2009): Greater than the sum of its parts: transition into the first year of undergraduate nursing.Nurse Educ. Pract. 2009 Jan;9(1):13-21. doi: 10.1016/j.nepr.2008.03.009. Available at: http://researchonline.gcu .ac.uk/portal/files/26965/online--full-text

3. Charles H., \& Kathleen, A., (2009): Quiz Corrections: Improving Learning by Encouraging Students to Reflect on Their Mistakes. The Physics Teacher. Vol. 47, December 2009 DOI: 10.1119/1.3264589.

4. Chaves, E., Simão, T., Oliveira I., Souza, I., Iunes, D., \& Nogueira, D., (2013): Assessment of nursing students' selfesteem at a university in the South of Minas Gerais (Brazil). Invest EducEnferm. 2013;31(2):261-269.

5. Clifton, D., McKillup, S., (2012): Why such success? Nursing students show consistently high satisfaction with bioscience courses at a regional university. Australian journal of advanced nursing, Volume 33 Issue 3. Available at: http://www.ajan.com.au/Vol33/Issue3 /3Clifton.pdf.

6. Douglass, C., \& Morris, R., (2014):Student perspectives on self-directed learning. Journal of the Scholarship of Teaching and Learning, Vol. 14, No. 1, February 2014, pp. 13 -25.doi: josotl.v14i1.3202.

7. Evans, C., \& Stevenson, K., (2009): The learning experiences of international doctoral students with particular reference to nursing students: a literature review. International Journal of Nursing Studies. doi:10.1016/j.ijnurstu.2009.05.025

8. Hakim, A., (2014): Nursing students'satisfaction about their field of study. International Journal of Nursing 2(2), 2014 Apr; 2(2): 82-87.

9. Health \& Life Skills Guide to Implementation HLSGI (2002): Instructional Strategies. Alberta Learning, Alberta Canada, 2002.p67.available at: https://education.alberta.ca/media/482311/is.pdf

10. Hiemstra, R., (1994): Self-directed learning. In T. Husen\& T.N. Postlethwaite (Eds.), The International Encyclopedia of Education (second edition), Oxford: Pergamon Press, 1994. Available at: http://ccnmtl.columbia.edu/projects/pl3p/SelfDirected\%20Learning.pdf

11. Iwasiw C., (2014): The role of the teacher in self-directed learning. Elsevier, 2014. Available at: http://www.sciencedirect.com/ science/ article

12. Joseph R. \& Hall P. (2009): Learning strategies. SIM (Srategiclnstructional Model, April 2009. Available at: http://www. kucrl.org/sim/ brochures/LSoverview.pdf

13- Joshua, C., (2013): The most successful students are those whofeel real "ownership" of their education. Available at http://novemberlearning .com/blog/2013

14. Kan E., Staber S. (2009): Fast factors for the clinical nursing instructor.2nd ed, Springer publishing company, 2009. Available at: http://www. Springerpub.com/product.

15. Marann, B., \& Barbara, F., (2005) A study of, accounting students' motives, expectations and preparedness for higher education, Journal of Further and Higher Education, 29:2, 111-124, DOI: $\quad 10.1080 / 03098770500103176$ http://dx.doi.org

16. 16- Nantz K., \& Klaf S., (2012): Putting the Spotlight on Learning: Cultivating Self-Directed Learners by Design. Annual Teaching Professor Conference.Washington . 3 June, 2012. p 4. 
17. Oxford, R., (2009): language learning styles and strategies: an overview. Learning Styles \& Strategies/Oxford, GALA 2003. Available at: http://web.ntpu.edu.tw/ language /workshop/read2.pdf

18. Reio, T., \& Choi, N., (2004): Novelty seeking in adulthood: Increases accompany decline. The Journal of genetic psychology, 165(2), 119-133

19. Reio, T., \& Davis, W., (2005): Age and gender differences in self-directed learning readiness: A developmental perspective. International Journal of Self-Directed Learning, 2(1), 40-49.

20. Rosenshine, B., (2012): Principles of Instruction: Research-Based Strategies That all teachers should know, American Educator, v36 n1 p12-19, 39 Spr 2012.

21. Saber K., (1995): Influence of clinical educational environment on the development of professional identity on nursing student. Unpublished Doctoral dissertation . Alexandria: Alex University, Faculty of nursing, 1995.

22. The Academy of Dental Therapeutics ant Stomatology TADTS (2014): ineedce.com. Active leaning strategies, 2014.Available at: www.ineedce.com.

23. Truby, D., (2010): What Really Motivates Kids. Instructor (119) no4 Jan/Feb. 2010 p. 26-9

24. Van Rensburg, G., \&Botma, Y., (2015): Bridging the gap between self-directed learning of nurse educators and effective student support. Curationis 38(2).

25- Walling, P., (2011): How did Nursing Become a Female Profession. Available at http://www.themale-nurse.com/2011/06/how-did-nursingbecome-female.html

26- Webster, R., (2012): Challenging Student Satisfaction through the Education of Desires. Australian Journal of Teacher Education,37(9).htp://dx.doi.org/10.14221/ajte.2 $012 \mathrm{v} 37 \mathrm{n} 9.6$

27- Williams, K., \& Williams, C., (2011): Five key ingredients for improving motivation. Research in Higher Education Journal, 11.http://aabri.com/manuscripts/11834.pdf 